\title{
Cryopreservation of dormant orthodox seeds of forest trees: mazzard cherry (Prunus avium L.)
}

\author{
Paweł CHMIELARZ* \\ Institute of Dendrology, Polish Academy of Sciences, Parkowa 5, 62-035 Kórnik, Poland
}

(Received 29 August 2008; accepted 26 November 2008)

\begin{abstract}
Keywords: desiccation / liquid nitrogen / seed storage / stratification / water content
\end{abstract}

\begin{abstract}
- The sensitivity of dormant seeds of mazzard cherry (Prunus avium L.) of Polish provenances to extreme desiccation and/or the ultra-low temperature of liquid nitrogen, $\mathrm{LN}\left(-196^{\circ} \mathrm{C}\right)$, was investigated to identify the optimum seed water content (w.c.) at this temperature.

- Germination and seedling emergence tests in this study showed that there is no critical seed w.c. for deeply desiccated seeds (stone w.c. 1.6\%), although such desiccated seeds were sensitive to the temperature of LN in the seedling emergence test. For seeds frozen in LN, the highest germinability was observed at w.c. of $9.0-16.9 \%$, but seedling emergence was then significantly lower than in nonfrozen seeds. The 2-year of storage in $\mathrm{LN}$ of seeds desiccated to $7.8 \%$ w.c. did not decrease germinability after thawing, in comparison with 2-year of storage at $-3{ }^{\circ} \mathrm{C}$. Storage in $\mathrm{LN}$ showed that if seeds were stored after breaking of their dormancy, germinability after storage was lower because of the necessity of seed desiccation to the lower level ( $\sim 8 \%)$ of w.c. after stratification (before storage). Secondary dormancy was induced in seeds desiccated after stratification.

- The results of this study demonstrate the potential for long-term cryopreservation of mazzard cherry seeds in forest gene banks.
\end{abstract}

\begin{abstract}
Résumé - La cryoconservation des semences dormantes orthodoxes des arbres forestiers : le merisier (Prunus avium L.).

- La sensibilité des semences dormantes de merisier (Prunus avium L.) de provenances polonaise à l'extrême dessiccation et/ou à l'ultra-basse température de l'azote liquide, $\mathrm{LN}\left(-196{ }^{\circ} \mathrm{C}\right)$, a été étudiée afin d'identifier l'optimum de teneur en eau (w.c.) des semences à cette température.

- Les tests de germination et émergence des plantules dans cette étude ont montré qu'il n'y a pas de teneur en eau critique (w.c.) pour les semences profondément déshydratées (teneur en eau 1,6\%), bien que ces graines desséchées soient sensibles à la température de la LN dans le test d'émergence des plantules. Pour les semences congelées dans LN, la plus forte capacité de germination a été observée à une teneur en eau de 9,0-16,9\%, mais l'émergence des semis a ensuite été beaucoup plus faible que dans les semences non congelées. Deux ans de stockage LN pour les semences déshydraté à une teneur en eau de 7,8\% n'a pas diminué la capacité de germination après décongélation, en comparaison avec 2 ans de stockage à $3{ }^{\circ} \mathrm{C}$. Le stockage en $\mathrm{LN}$ a montré que si les semences ont été stockées après la levée de leur dormance, leur capacité de germination après stockage a été plus faible en raison de la nécessité d'une dessiccation à un faible teneur en eau $(\sim 8 \%)$ après stratification (avant stockage). Une dormance secondaire a été induite chez des semences déshydratées après stratification. - Les résultats de cette étude démontrent le potentiel, pour une cryopréservation à long terme, des semences de merisier dans des banques forestières de gènes.
\end{abstract}

\section{INTRODUCTION}

Roberts (1973) divided seeds of various plant species into two categories: orthodox and recalcitrant. Ellis et al. (1990), on the basis of an additional criterion, i.e., the effect of stor-

*Corresponding author: pach@man.poznan.pl age time after deep dehydration, introduced a third category of suborthodox or intermediate.

Orthodox seeds are usually stored according to the standard methods at $-18{ }^{\circ} \mathrm{C}$ (FAO/IPGRI, 1994). Long-term storage of orthodox seeds in gene banks can involve their cryopreservation in liquid nitrogen (LN) (Pence, 1991; Touchell and Dixon, 1993; Stanwood, 1985; Wang et al., 1993). A key problem in 
the cryopreservation of orthodox seeds is the identification of their optimum (safe) water content (w.c.). Wang et al. (1993) suggest that the safe range of w.c. of seeds preserved in $\mathrm{LN}$ is $3.8-11 \%$. In general, studies performed at the National Center for Genetic Resources Preservation in Fort Collins, CO, showed that the lower the storage temperature, the longer the storage life of the seeds (Walters et al., 2004). However, cryopreservation is not sufficient to stop the processes leading to the deterioration of seed quality, particularly if the processes of aging have already been initiated (before cryopreservation) at the higher storage temperature (Walters et al., 2004).

There is some research concerning plant growth and low temperatures (Fernandez et al., 2007; Jacobs et al. 2008; Luis et al., 2007) but only fragmentary data have been published on the effects of deep dehydration of seeds (Suszka, 1967), and none on the effects of cryopreservation on the germinability of mazzard cherry (Prunus avium) seeds. Successful cryopreservation in the genus Prunus has involved zygotic embryos, apical meristems cultured earlier in vitro (Brison et al., 1995; Helliot and de Boucaud, 1997; Niino et al., 1997; Shatnawi et al., 1999), embryogenic tissue (Grenier et al., 2005) and dormant buds (Katano and Irie, 1991; Towill and Forsline, 1999). No published data are available about seed germination and seedling emergence after cryopreservation of mazzard cherry seeds. The word "seed", also used later in this work, refers to the true seed with the endocarp (true seed + endocarp = stone), which is the germination unit for mazzard cherry.

Seeds of mazzard cherry tolerate drying to $9 \%$ w.c., at which they can be stored (without viability loss) for 4.5 or $5 \mathrm{y}$ at $1{ }^{\circ} \mathrm{C}$ (Grisez, 1974; Suszka, 1970), and even for $7 \mathrm{y}$ at $-3^{\circ}$ to $-5{ }^{\circ} \mathrm{C}$ (Soloveva, 1966). Seeds have been dried to $10 \%$ w.c. and then stored for 48 months in LN. The tetrazolium test TTC (Triphenyl tetrazolium chloride) of embryos after thawing detected no decrease in seed viability, as compared with nonfrozen control seeds (Kuhn et al., 1995).

The main hypothesis of these investigations was that seeds of mazzard cherry can be stored in LN without loss of viability. Sensitivity of seeds of Polish provenances to deep dehydration and the very low temperature of $\mathrm{LN}\left(-196^{\circ} \mathrm{C}\right)$ was assessed. The research addressed determination of the safe and critical w.c. of dried seeds (sensitivity to deep dehydration) and determination of the range of safe w.c. of seeds frozen in LN (freezing for $24 \mathrm{~h}$ at $\left.-196^{\circ} \mathrm{C}\right)$. Another important question was the influence of longer storage (for $2 \mathrm{y}$ ) of seeds in LN on germination and seedling emergence after thawing, with the use of dormant seeds and of seeds whose dormancy was broken (after stratification).

\section{MATERIALS AND METHODS}

\subsection{Plant material}

Mazzard cherry (Prunus avium L.) seeds of two provenances in southeastern Poland (Zwierzyniec in Roztocze, and the Bieszczady Mts.) were collected when ripe, in 2000 and 2001. Next, they were dried to $13 \%$ w.c., and their germination was tested. Germination reached $35 \%$ and $91 \%$ for seeds from Zwierzyniec and the Bieszczady Mts., respectively.

\subsection{Water content of seeds}

The seed water content refers in this paper to the w.c. of the true seed plus endocarp $=$ stones (up to $1-2 \%$ of stones, depending on provenance, were empty - endocarp without true seeds).

Depending on the planned seed w.c., seeds with initial w.c. of $13 \%$ were dried over silica gel or moistened in a tightly closed vessel, and the seed sample weight was controlled. The required weight of seeds, corresponding to the measured w.c., was calculated using a previously described formula (Suszka, 1975).

To reach a higher w.c. (moisturization), seeds were sprayed several times with water to a specified weight and then left in tightly closed containers (conditioning) for $5-7$ days at $3{ }^{\circ} \mathrm{C}$ to even out the w.c. of the endocarp and true seed. Seed w.c. levels lower than $10 \%$ were reached by slow desiccation above dry silica gel. The desiccation lasted no longer than 2-3 weeks (drying to the lowest levels of w.c., ca. $2 \%$ ). However, the duration of drying seeds to the higher $(>2 \%)$ levels of w.c. was usually from one to several days. The seeds were placed on blotting paper (in a layer with a thickness not exceeding double the seed height) in a box (25 cm long, $15 \mathrm{~cm}$ wide, $9 \mathrm{~cm}$ high) filled with dry silica gel (200 g).

Differences between 15 individual seed w.c. levels were usually about $2 \%$, within a w.c. range of $2-30 \% \pm 1 \%$.

The w.c. of seeds was assessed each time in 3 replications of 10 seeds each by drying them at $103 \pm 2{ }^{\circ} \mathrm{C}$ for $17 \mathrm{~h}$. The w.c. of seeds was expressed as a percentage of the fresh weight basis.

Drying of stratified seeds, before storage for 1 or 2 y in LN or at $-3{ }^{\circ} \mathrm{C}$, was conducted at room temperature for $1-2$ days to a w.c. level within the desired, previously determined, safe range of w.c. The range was determined on the basis of tolerance to the temperature of $\mathrm{LN}$ for $24 \mathrm{~h}$ by seeds with 15 levels of w.c. (range 2-30\%, provenance Bieszczady Mts.).

\subsection{Stratification}

The substrate for seed stratification was a moist mixture (v/v, 1:1) of quartz sand fraction $<1 \mathrm{~mm}$ with sieved peat of $\mathrm{pH} 3.5-4.5$. The stratification substrate was kept moist (Gordon and Rowe, 1982). Seeds mixed with the substrate at a ratio of 1:3 were placed in 0.25liter plastic bottles. Each bottle was closed with a lid with several holes $0.5 \mathrm{~cm}$ in diameter, which enabled gas exchange with ambient air and simultaneously protected the substrate with seeds against excessive drying. The condition of seeds and the substrate was controlled every week during warm stratification at $25^{\circ} \mathrm{C}$, and every $2-3$ weeks during cold stratification at $3{ }^{\circ} \mathrm{C}$. Soon before germination, the intervals between controls were reduced to 1 week. During the periodical controls, the water level of the stratification substrate was checked, and water was added by spraying, if necessary. In addition, the condition of seeds was observed (fungal infections, insect larvae), and the first germinated seeds were counted (i.e., those with radicles 2-3 $\mathrm{mm}$ long, which are visible signs of dormancy release) if any appeared.

Stratification of the seeds of mazzard cherry was conducted in a substrate, in a warm-cold-warm-cold system at $25{ }^{\circ} \mathrm{C}$ for 2 weeks, $3{ }^{\circ} \mathrm{C}$ for 2 weeks, $2{ }^{\circ} \mathrm{C}$ for 2 weeks, and $3{ }^{\circ} \mathrm{C}$ for 12 weeks, i.e. until the appearance of the first germinating seeds (Suszka, 1962; 1967). 


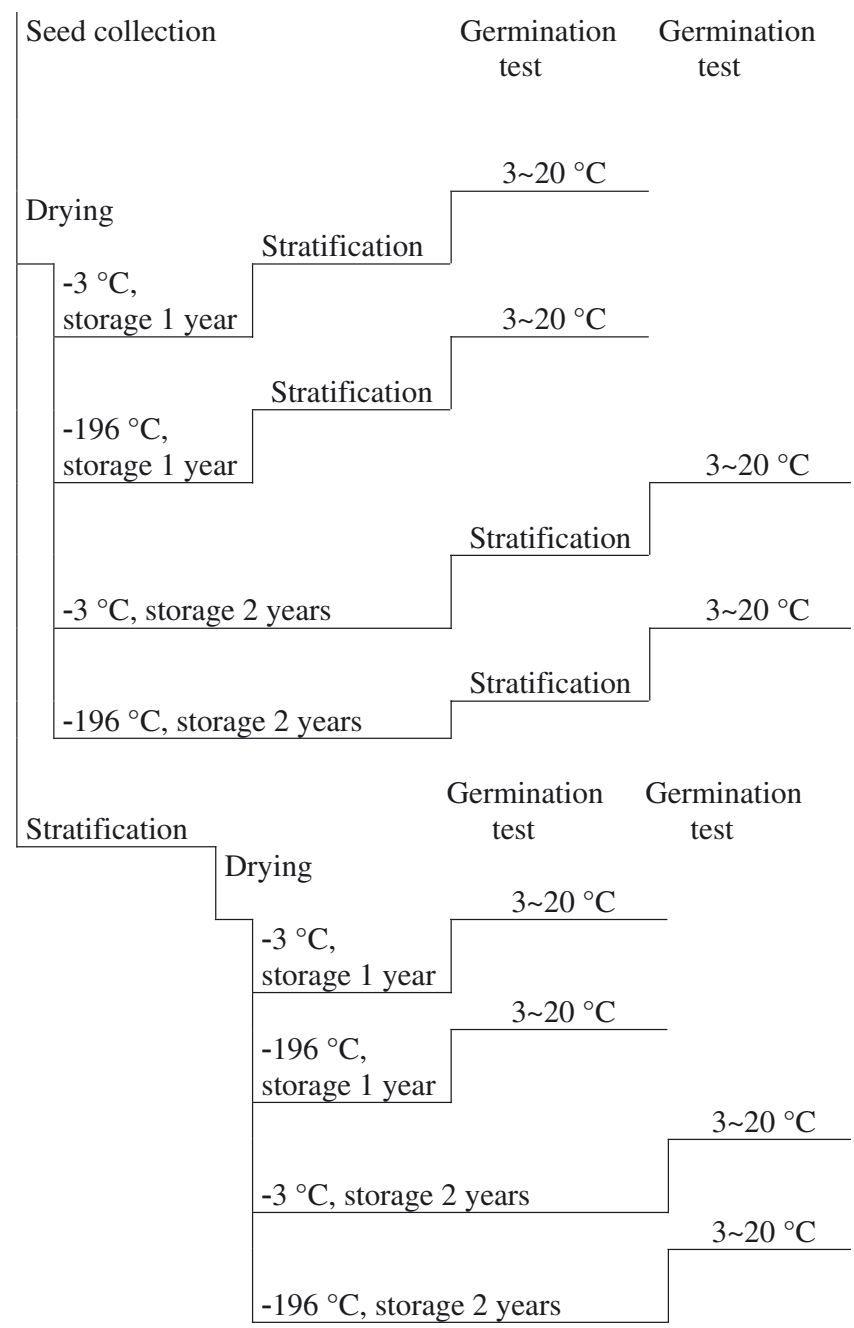

Figure 1. Prunus avium L. Scheme of storage of dormant seeds (before or after stratification) for 1 or 2 y at $-3{ }^{\circ} \mathrm{C}$ (control) or $-196{ }^{\circ} \mathrm{C}$. Stratification at $25^{\circ} \mathrm{C} / 3{ }^{\circ} \mathrm{C} / 25^{\circ} \mathrm{C} / 3{ }^{\circ} \mathrm{C}$ was applied, and the germination test was conducted at cyclically alternating temperatures of $3 \sim 20{ }^{\circ} \mathrm{C}$, $16+8 \mathrm{~h}$ a day.

\subsection{Cryopreservation}

Before freezing at the temperature of $\mathrm{LN}$, the seeds were placed in CryoFlex tubes (polyethylene, elastic cylinders ca. $1 \mathrm{~cm}$ in diameter, 5-15 cm long, sealed at both ends).

During storage for 1 and $2 \mathrm{y}$, the seeds tightly sealed in CryoFlex tubes were placed in a 100-L programable freezer (Cryoson $\mathrm{GmbH}$, Germany). The material was frozen by direct plunging into LN. Samples of seeds were stored in $\mathrm{LN}$ throughout the study period. Control seeds were stored in a similar way at $-3{ }^{\circ} \mathrm{C}$ (Figs. 2 and 3). To assess the effect of storage before and after dormancy breaking on seed viability, the seeds were stored at the temperatures mentioned above before or after stratification (Fig. 2). The level of LN in the freezer with the samples was controlled for 2 y by a NR2A-10 alarm, Cryoson $\mathrm{GmbH}$, Germany, which signalled the minimum and maximum level of $\mathrm{LN}$, and it was automatically replenished.

After storage in LN, CryoFlex tubes containing seeds were thawed at $40{ }^{\circ} \mathrm{C}$ in a water bath for $15 \mathrm{~min}$. After storage at $-3{ }^{\circ} \mathrm{C}$, the seeds were thawed at room temperature.

\subsection{Germination and emergence tests}

Seed germination tests were performed after stratification in darkness, in a similar substrate and bottles to those used for seed stratification. Optimum thermal conditions for seed germination were ensured by cyclically alternating temperatures of $3 \sim 20{ }^{\circ} \mathrm{C} /(16+8 \mathrm{~h}$ a day), (Suszka, 1967). Every week, germinated seeds were counted and water in the substrate was replenished.

Seedling emergence tests were conducted in boxes in a mixture of sand with peat, similar to that used for the stratification and germination tests. This time, seeds after stratification were sown in the substrate at a depth of $1 \mathrm{~cm}$, and covered with a layer of sand. To ensure suitable moisture, the boxes were covered with a transparent lid (allowing penetration of light to emerging seedlings), which was removed when seedlings reached ca. $2-3 \mathrm{~cm}$ in height. Emergence tests, like germination tests, were conducted at cyclically alternating temperatures $\left(3 \sim 20{ }^{\circ} \mathrm{C}, 16+8 \mathrm{~h}\right.$ a day), (Suszka, 1967), until seedlings reached ca. $2-3 \mathrm{~cm}$ in height. Boxes with seedlings were then moved into light $\left(60 \mu \mathrm{mol} \cdot \mathrm{m}^{-2} \mathrm{~s}^{-1}\right.$ for $16 \mathrm{~h}$ a day $)$, to a chamber with a controlled temperature of $25^{\circ} \mathrm{C}$. 


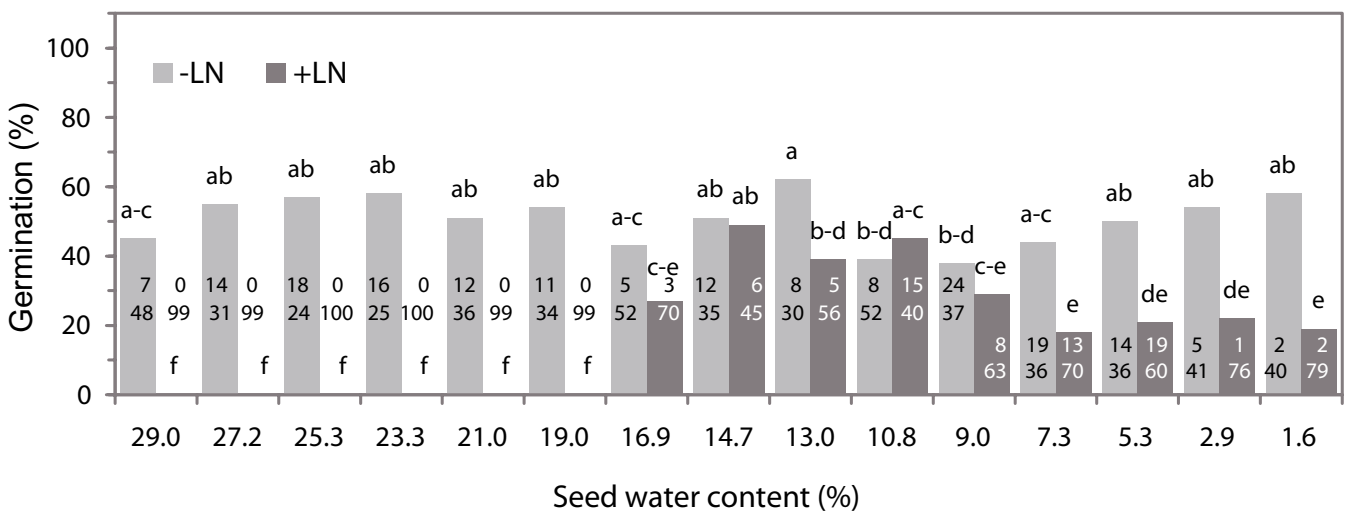

Figure 2. Prunus avium L. Seed germination after drying or moisturizing of seeds to 15 levels of water content (1.6-29.0\%), untreated (-LN) and treated $(+\mathrm{LN})$ with liquid nitrogen for $24 \mathrm{~h}$. Nongerminated seeds were finally classified as: healthy (in \%, upper row of numbers) or decayed (in $\%$, lower row of numbers); up to $2 \%$ of seeds were empty. Tukey test, the values marked with the same letter are not significantly different at $P<0.05$, provenance Bieszczady Mts. (SE Poland).

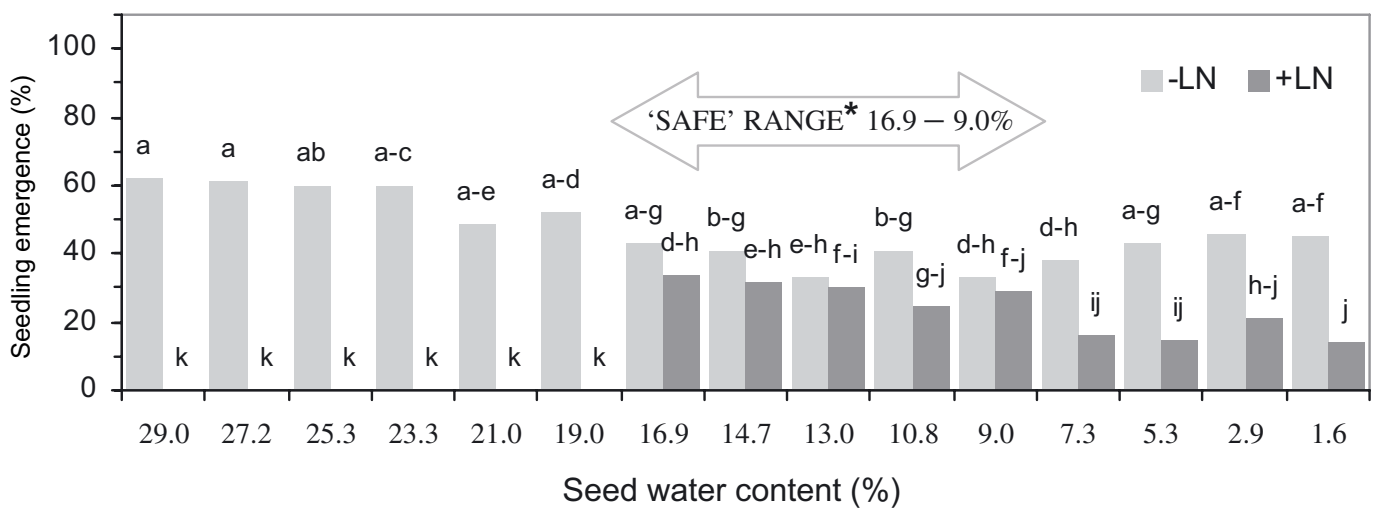

Figure 3. Prunus avium L. Seedling emergence after drying or moisturizing of seeds to 15 levels of water content (1.6-29.0\%), untreated $(-\mathrm{LN})$ and treated $(+\mathrm{LN})$ with liquid nitrogen for $24 \mathrm{~h}$. Tukey test, the values marked with the same letter are not significantly different at $P<0.05$, provenance Bieszczady Mts. (SE Poland).

* In inverted commas because seedling emergence after thawing from LN was seriously lower even within this range (9.0-16.9\%) as compared with the control (nonfrozen) seeds. Regardless, this was the most favorable range of water content for seeds frozen in LN, determined on the basis of seedling emergence (Fig. 3) and germination (Fig. 2).

\subsection{Applied nomenclature concerning seed evaluation and germination tests}

The term "cutting test" in this work was used to denote seed viability evaluation $(4 \times 50$ seeds $)$ performed after collection (initial evaluation) and after the stratification and germination test (final evaluation). The true seeds, after removal from the hard endocarp, were cut along the longitudinal axis (with a knife), across cotyledons and the embryo axis.

In the group of nongerminated seeds (did not germinate until the end of the germination test), the following groups of seeds were distinguished: healthy, decayed and empty. The results are presented in $\%$, as a mean of all replications, for each fraction separately. Healthy seeds had white, fleshy, and shiny cotyledons and embryo axes and thus were capable of further development into normal seedlings. Seeds that decayed partly or completely as a result of primary infection (i.e., originating from this seed) were classified as decayed seeds. Such seeds did not develop into seedlings. Empty seeds were also distinguished by their containing less than $50 \%$ of seed tissue.

\subsection{Statistical analysis}

For statistical analysis of the data, STATISTICA software (StatSoft Polska, 1995-2005) was used. To analyze the significance of differences between means, analysis of variance (ANOVA) was applied, as was the Tukey test for pair-wise comparisons. Before ANOVA analysis the percentage data were transformed into arc-sin values. The Tukey test was performed at a significance level of $P<0.05$. Separate ANOVAs and Tukey tests were performed for germination and emergence. All variables used in the experiments (time of seed storage, method of seed storage, seed storage temperature) were fixed. Three-way ANOVA was used for Tables: time of storage (1 or $2 \mathrm{y}$ ), method of seed storage (before or after stratification) and storage 

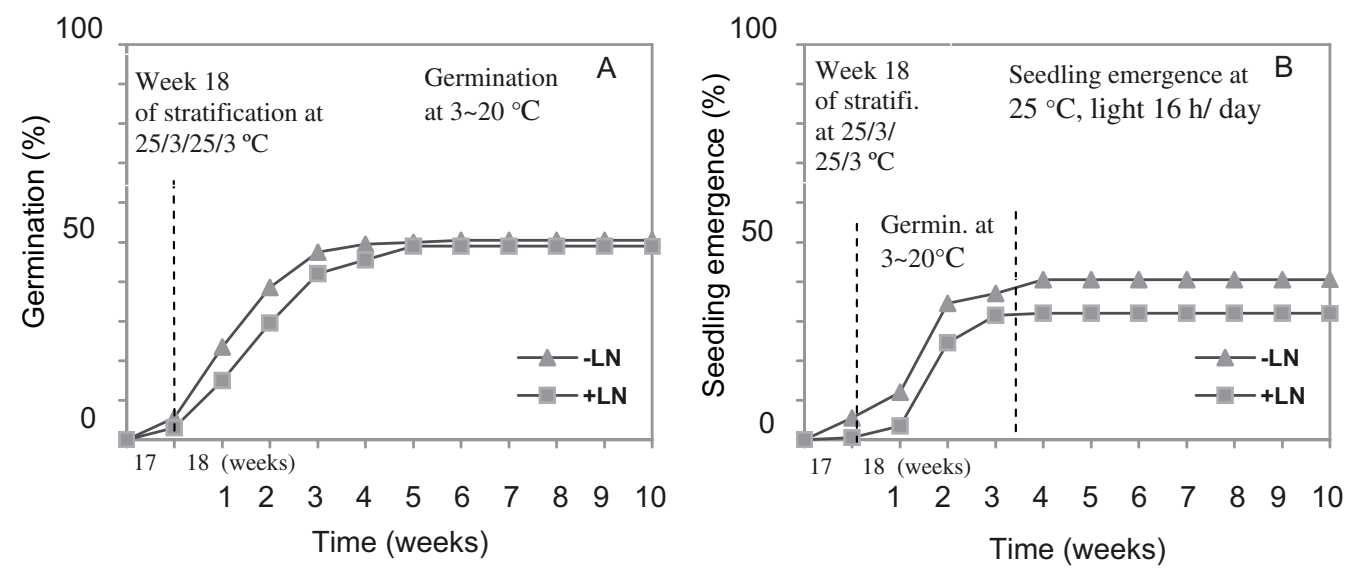

Figure 4. Prunus avium L. Germination (A) and seedling emergence (B) courses for seeds with a water content of $14.7 \%$, untreated (-LN) and treated $(+\mathrm{LN})$ with liquid nitrogen for $24 \mathrm{~h}$, provenance Bieszczady Mts. (SE Poland).

temperature $\left(-3^{\circ} \mathrm{C}\right.$ or $\left.-196^{\circ} \mathrm{C}\right)$. Two-way ANOVA was used for Figures 2 and 3: the seed water content ( 15 levels of seed water content) and the seed treatment $(-\mathrm{LN},+\mathrm{LN})$. One-way ANOVA was used for Figure 5A (the seed storage: nonstratified $(\mathrm{nS})$ or stratified $(\mathrm{S}))$ and for Figure $5 \mathrm{~B}$ (the temperature of seed storage: $-3{ }^{\circ} \mathrm{C}$ or $-196{ }^{\circ} \mathrm{C}$.

In laboratory tests of germination and emergence, each experimental variant included 4 replications of 50 seeds each.

\section{RESULTS}

Nonfrozen mazzard cherry seeds tolerated drying to the lowest of the studied levels of w.c., 1.6\%. After stratification, $58 \%$ of desiccated seeds germinated, and $33-45 \%$ of seedlings emerged (Figs. 2, 3).

Deep dehydration of seeds, below $7.3 \%$, down to $1.6 \%$ w.c., was accompanied by a gradual increase in germination. As a result, germination increased from $44 \%$ to $58 \%$ (difference not significant) (Fig. 2).

The results of germination tests after storage in LN showed that mazzard cherry seeds tolerated freezing at the temperature of LN within the w.c. range of $9.0-16.9 \%$ (Fig. 2). The results of emergence tests indicated a similarly favorable w.c. range (Fig. 3), although the values were slightly lower than for the nonfrozen seed material.

Within the seed w.c. range of $1.6-7.3 \%$, seeds frozen in LN had a lower viability (Figs. 2 and 3). Seedling emergence for seeds frozen in $\mathrm{LN}$ within the w.c. range of $9.0-16.9 \%$ was ca. $10 \%$ lower than for nonfrozen seeds with the same w.c. (Fig. 3).

Seedling emergence for seeds frozen in $\mathrm{LN}$ at w.c. of $7.3 \%$ and $19 \%$ was about $16 \%$ and $0 \%$, respectively. Germination and seedling emergence for a seed w.c. range of 19-29\%, after freezing in LN, also amounted to $0 \%$ (Figs. 2 and 3)

In addition, for the seeds that had not been frozen in $\mathrm{LN}$, after moisturization to w.c. of 16.9-29\%, seedling emergence was significantly higher than for seed w.c. of about $10 \%$ (Fig. 3).

Mazzard cherry seeds, after freezing in $\mathrm{LN}$ at $14.7 \%$ seed w.c., germinated less vigorously than nonfrozen seeds during the first 3 weeks (Fig. 4A). Final germination of seeds treated and untreated with LN were similar at the end of germination tests. Shoots obtained from seeds treated with LN developed more slowly throughout the seedling emergence test, as compared with control seeds (not frozen in LN). The final percentage of seedlings, after 10 weeks of observations of emergence from the seeds that were not treated with $\mathrm{LN}$, was also higher than for the seeds that were frozen in LN (Fig. 4B).

It was more favorable to store nonstratified seeds (A) than stratified seeds (B) for $1-2 \mathrm{y}$ in $\mathrm{LN}$ (also at $-3{ }^{\circ} \mathrm{C}$ ) (Tabs. I and II). The seeds stored at this w.c. before stratification were characterized by germination of $27-45 \%$, while those stored after stratification showed germination of $5-13 \%$. Corresponding seedling emergence was $13-40 \%$ and $1-3 \%$ (Fig. 5A).

The temperatures of $-3{ }^{\circ} \mathrm{C}$ and $-196{ }^{\circ} \mathrm{C}$ did not differentiate germination $(23 \%$ and $21 \%$, differences not significant, letter $a$ Fig. 5B), while seedling emergence after freezing in LN was significantly lower $(9 \%$, mean of $2 \mathrm{y}$, letter B, Fig. 5B) than after storage at $-3{ }^{\circ} \mathrm{C}(18 \%$, mean of $2 \mathrm{y}$, letter A, Fig. 5B).

Slow drying to seed w.c. of $7.8 \%$ after stratification (before storage, B), caused a decrease in seed germination from $30 \%$ to $5-13 \%$ (Tab. 8 and footnotes); thus, it significantly affected the germination and seedling emergence after storage, as compared with the seeds stratified after storage (A).

\section{DISCUSSION}

\subsection{Deep seed dehydration}

Mazzard cherry seeds in this study tolerated severe drying, to $2 \%$ w.c., as also reported earlier by Jensen and Eriksen (2001). In addition, as the w.c. of seeds decreased, their germination gradually slightly increased. A higher germination of mazzard cherry after $1 \mathrm{y}$ of storage of dried seeds, as compared with that of seeds stratified soon after collection, was observed by Sebök (1968). This suggests that mazzard cherry seeds tolerate deep dehydration very well. 
Table I. Prunus avium L. Germination after seed storage with water content (w.c.) of $7.7 \%$ before dormancy release (A) and w.c. of $7.8 \%$ after dormancy release (B) for 1 or $2 \mathrm{y}$ at $-3{ }^{\circ} \mathrm{C}$ (control) or $-196^{\circ} \mathrm{C}$. Tukey test, the values marked with the same letter are not significantly different at $P<0.05$, provenance Zwierzyniec (Roztocze, SE Poland).

\begin{tabular}{|c|c|c|c|c|}
\hline \multirow[t]{3}{*}{ Storage time } & \multirow{3}{*}{\multicolumn{2}{|c|}{$\begin{array}{c}\text { Storage } \\
\text { temperature } \\
{ }^{\circ} \mathrm{C}\end{array}$}} & \multicolumn{2}{|c|}{ Germination $(\%)$} \\
\hline & & & storage $\rightarrow$ stratification & stratification $\rightarrow$ storage \\
\hline & & & (A) & (B) \\
\hline \multirow[t]{2}{*}{$1 \mathrm{y}$} & \multicolumn{2}{|c|}{-3} & $29 \mathrm{ab}$ & $8 \mathrm{~cd}$ \\
\hline & \multicolumn{2}{|c|}{-196} & $37 \mathrm{a}$ & $5 \mathrm{~d}$ \\
\hline \multirow[t]{2}{*}{$2 \mathrm{y}$} & \multicolumn{2}{|c|}{-3} & $45 \mathrm{a}$ & $6 \mathrm{~d}$ \\
\hline & \multicolumn{2}{|c|}{-196} & $27 \mathrm{abc}$ & $13 \mathrm{bcd}$ \\
\hline ANOVA & df & df ERROR & $\mathrm{F}$ & $P$ \\
\hline S. Time & 1 & 24 & 1.31 & 0.2632 \\
\hline S. Method & 1 & 24 & 70.77 & $0.0000 *$ \\
\hline S. Temp. & 1 & 24 & 0.21 & 0.6529 \\
\hline S. Time $\bullet$ S. Method & 1 & 24 & 0.16 & 0.6938 \\
\hline S. Time $\bullet$ S. Temp. & 1 & 24 & 0.25 & 0.6248 \\
\hline S. Method $\bullet$ S. Temp. & 1 & 24 & 0.65 & 0.4279 \\
\hline S.TimeS $\bullet$ S. Method $\bullet$ S. Temp. & 1 & 24 & 7.72 & 0.0104 \\
\hline
\end{tabular}

ANOVA - variables: S. Time - time of seed storage (1 or 2 y), S. Method - the method of seed storage (stored before stratification - A or after stratification - B), S. Temp. - the storage temperature $\left(-3{ }^{\circ} \mathrm{C}\right.$ or $\left.-196{ }^{\circ} \mathrm{C}\right)$. $*$ In bold are $P<0.05$.

Nongerminated seeds: decayed (52-92\%), healthy seed (2-5\%) and up to $1 \%$ empty.

Germination from nonfrozen seeds after stratification (without seed desiccation): $30 \%$ (nongerminated seeds: $66 \%$ decayed, $4 \%$ healthy).

Germination from nonfrozen seeds after their stratification and desiccation (to w.c. of $7.8 \%$ ): $10 \%$ (nongerminated seeds: $89 \%$ decayed, $1 \%$ healthy).

Table II. Prunus avium L. Seedling emergence after seed storage with water content (w.c.) of 7.7\% before dormancy release (A) and w.c. of $7.8 \%$ after dormancy release (B) for 1 or $2 \mathrm{y}$ at $-3{ }^{\circ} \mathrm{C}$ (control) or $-196{ }^{\circ} \mathrm{C}$. Tukey test, the values marked with the same letter are not significantly different at $P<0.05$, provenance Zwierzyniec (Roztocze, SE Poland).

\begin{tabular}{|c|c|c|c|c|}
\hline \multirow[t]{3}{*}{ Storage time } & \multirow{3}{*}{\multicolumn{2}{|c|}{$\begin{array}{c}\text { Storage } \\
\text { temperature } \\
{ }^{\circ} \mathrm{C} \\
\end{array}$}} & \multicolumn{2}{|c|}{ Seedling emergence $(\%)$} \\
\hline & & & storage $\rightarrow$ stratification & stratification $\rightarrow$ storage $(\mathrm{B})$ \\
\hline & & & (A) & (B) \\
\hline \multirow[t]{2}{*}{$1 \mathrm{y}$} & \multicolumn{2}{|c|}{-3} & $24 \mathrm{ab}$ & $1 \mathrm{~cd}$ \\
\hline & \multicolumn{2}{|c|}{-196} & $17 \mathrm{~b}$ & $1 \mathrm{~d}$ \\
\hline \multirow[t]{2}{*}{$2 \mathrm{y}$} & \multicolumn{2}{|c|}{-3} & $40 \mathrm{a}$ & $3 \mathrm{~d}$ \\
\hline & \multicolumn{2}{|c|}{-196} & $13 \mathrm{bc}$ & $2 \mathrm{~d}$ \\
\hline ANOVA & df & df ERROR & $\mathrm{F}$ & $P$ \\
\hline S. Time & 1 & 24 & 0.56 & 0.4604 \\
\hline S. Method & 1 & 24 & 114.33 & 0.0000 \\
\hline S. Temp. & 1 & 24 & 13.48 & 0.0012 \\
\hline S. Time $\bullet$ S. Method & 1 & 24 & 0.49 & 0.4915 \\
\hline S. Time • S. Temp. & 1 & 24 & 0.88 & 0.3578 \\
\hline S. Method • S. Temp. & 1 & 24 & 3.04 & 0.0941 \\
\hline S. Time $\bullet$ S. Method $\bullet$ S. Temp. & 1 & 24 & 4.44 & 0.0458 \\
\hline
\end{tabular}

ANOVA - variables: S. Time - time of seed storage (1 or 2 y), S. Method - the method of seed storage (stored before stratification - A or after stratification - B), S. Temp. - the storage temperature $\left(-3{ }^{\circ} \mathrm{C}\right.$ or $\left.-196{ }^{\circ} \mathrm{C}\right)$. * In bold are $P<0.05$.

Emergence from nonfrozen seeds after their stratification (without seed desiccation): $19 \%$.

Emergence from nonfrozen seeds after stratification and desiccation of seeds (to w.c. of $7.8 \%$ ): $8 \%$. 

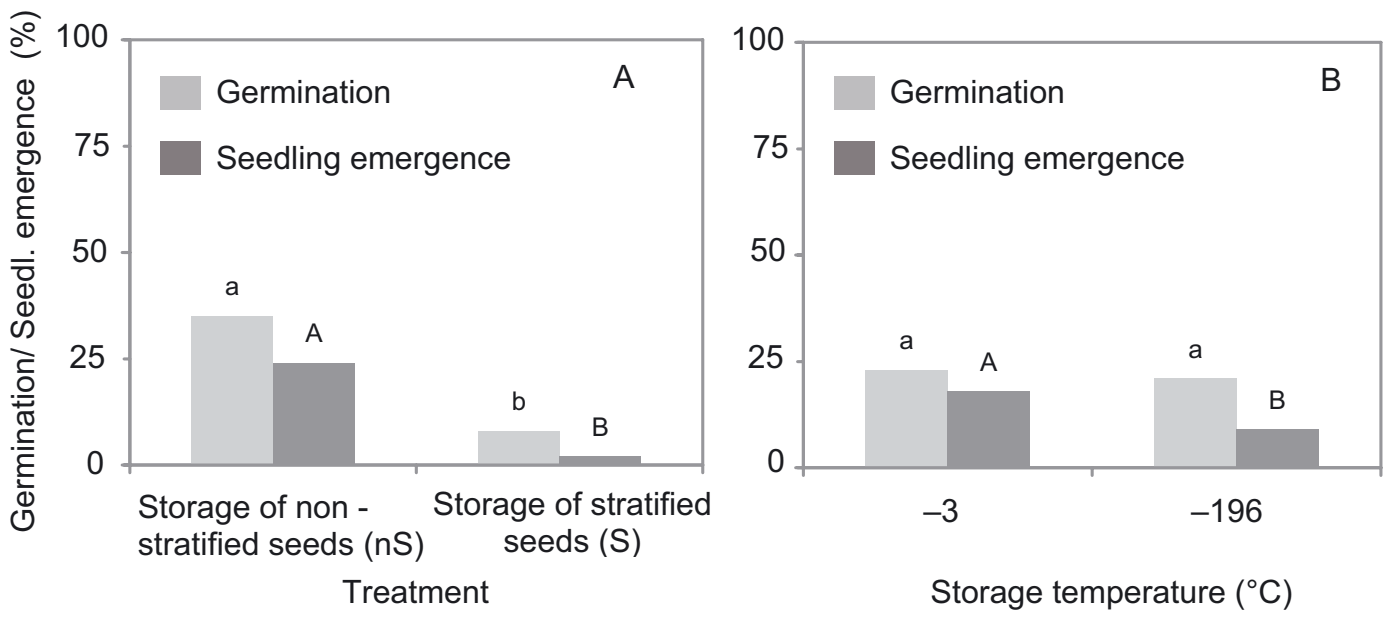

Figure 5. Prunus avium L. Effect of storage for 2 y of nonstratified (nS) and stratified (S) seeds (A), at $-3{ }^{\circ} \mathrm{C}$ or $-196{ }^{\circ} \mathrm{C}(\mathrm{B})$, on germination and seedling emergence. Values are means of results obtained after 1 or 2 y of storage. Two separate ANOVAs and four Tukey tests, the values marked with the same letter (small letters - germination, capital letters - emergence) are not significantly different at $P<0.05$, provenance Zwierzyniec (Roztocze, SE Poland).

\subsection{Why did deeply desiccated mazzard cherry seeds not tolerate the temperature of liquid nitrogen?}

Mazzard cherry seeds tolerate drying and storage at temperatures below $0{ }^{\circ} \mathrm{C}$ (Soloveva, 1966), but there are also some reports that seeds dried to $9 \%$ w.c. did not tolerate temperatures lower than $-40{ }^{\circ} \mathrm{C}$, which was probably associated with the phase transition of membranes from the liquid crystalline to the crystalline phase (Stanwood, 1985). Another publication (Grześkowiak et al., 1983) also attested to some damage to mazzard cherry seeds after 3 y of storage at $-18{ }^{\circ} \mathrm{C}$ in a dehydrated state (9-10\%) in tightly closed containers.

A large proportion of storage materials accumulated in mazzard cherry seeds (45\%) are lipids (Kamel and Kakuda, 1992) in the form of triglycerides (Bernardo-Gil et al., 2001). Seeds of Cuphea carthagenesis [a mazzard herb found in Mexico and Central and South America (Graham, 1988)], classified as suborthodox (intermediate), contain large amounts of storage lipids, very much like mazzard cherry seeds, and they lose the ability to germinate during storage at $5^{\circ} \mathrm{C}$ at high w.c. levels $(<5 \%)$ (Crane et al., 2006). Mazzard cherry seeds have a high tolerance to the temperature of $-18{ }^{\circ} \mathrm{C}$ (only a small decrease in seed germination rate: Grześkowiak and Suszka, 1983) as compared with seeds of $C$. carthagenesis, which die at $5{ }^{\circ} \mathrm{C}$ (Crane et al., 2006). This enhanced tolerance may result from differences in the fatty acid composition of the seeds in respect to the temperature of phase transition and seed sensitivity to low temperatures. Storage lipids in mazzard cherry seeds are composed mostly of unsaturated fatty acids, with long chains of carbon atoms. Such seeds tolerate freezing at lower temperatures (Crane et al., 2003). Mazzard cherry seeds contain mostly linoleic acid (C18:2), with a thawing temperature of $-26{ }^{\circ} \mathrm{C}$ (Small, 1986), and oleic acid (C18:1), with a phase transition temperature of $-12{ }^{\circ} \mathrm{C}$ (Small, 1986). Seeds containing large amounts of lipids composed of unsaturated fatty acids can sometimes be protected against the negative ef- fects of phase transition by a short warm treatment $\left(45^{\circ} \mathrm{C}\right)$ (Crane et al., 2003; Hoekstra et al., 2001). In our research, specific lipid composition in seeds of mazzard cherry could be a reason for the seriously lower level of seedling emergence derived from seeds stored in LN in the "safe" range of w.c.

Kuhn et al. (1995) stored seeds of mazzard cherry in LN for $48 \mathrm{~h}$, dried to $10 \%$ w.c. In contrast to the results of the current study, they did not observe during the analysis of dehydrogenase activity (in the tetrazolium test) any decrease in seed viability as compared with nonfrozen seeds. It can be concluded from our earlier research on seeds of European beech (Fagus sylvatica) and sycamore (Acer pseudoplatanus) that the TTC test of embryos is not a reliable method for seed viability evaluation in either species treated with the temperature of $\mathrm{LN}$, as compared with the results of the seedling emergence test (Chmielarz, unpubl. data).

The example of mazzard cherry shows that safe drying may not be the key condition for successful seed cryopreservation. Thus, seeds tolerant to drying should be the subject of separate cryogenic research to determine their reaction to the temperature of LN. As a result of this study, we classified mazzard cherry seeds as tolerant to deep dehydration but damaged by ultra-low temperatures.

\subsection{Seed storage in LN, dormancy, and secondary dormancy of stored seeds}

In the experiment on seed storage for $2 \mathrm{y}$ in $\mathrm{LN}$, an additional factor was included, i.e., the effect of stratification conducted in two variants: after seed storage [the typically applied sequence of actions, as in conventional seed storage (Suszka et al., 1996; Tylkowski, 1995, 1998)] or before it (Tylkowski, 1995). Seed storage after stratification is associated with the necessity of lowering their high w.c., observed during stratification, to the level of ca. $10 \%$, at which seeds are normally 
stored. Such desiccation was conducted at room temperature, which can contribute to the reduction of germination in some species subjected to this procedure (Bonner, 1984; Tylkowski, 1995). This suggests that the major factor causing the decrease in germination capacity could be the time of seed storage after stratification and drying, and not the fact of their drying, as also reported by Jones et al. (1998). Kamiński (1974) showed for apple seeds (cv. Antonówka) that the seeds that were almost completely prepared for germination (on day 88 of stratification) were the least sensitive to drying after stratification, as compared with seeds at an early stage of stratification. In the current study, desiccation of mazzard cherry seeds at $23{ }^{\circ} \mathrm{C}$, when they were at the final cold stage of stratification, caused a decrease in their germination. Healthy seeds that did not germinate probably developed secondary dormancy arising from seed drying after stratification at $23{ }^{\circ} \mathrm{C}$. However, it is not known if the secondary dormancy was caused by high temperature (Suszka, 1967), which affected for a short time the seeds that were losing water during desiccation, or only by the decrease in w.c. of seeds after stratification.

In molecular research on secondary dormancy in mazzard cherry seeds, interruption of the cold stage of stratification at $3{ }^{\circ} \mathrm{C}$ by raising the temperature to $20{ }^{\circ} \mathrm{C}$ caused a decrease in expression of the gene responsible for dormancy release (Pa-RRM-GRP1 = Prunus avium RNA recognition motif glycine-rich protein 1), a change observed during the cold stage of stratification (Stephen et al., 2003). As a result of secondary dormancy of seeds, two other genes also apparently were not expressed: $P a-P P 2 C 1=$ a serine/threonine protein-phosphatase $2 \mathrm{C}$ homologous to ABSCISIC ACID INSENSITIVE 1 and 2 , and $3 P a-A B I 3=$ the transcription factor ABSCISIC ACID INSENSITIVE, which appeared during primary dormancy in embryo axes of this species (Stephen et al., 2003). Thus, different genes control primary and secondary dormancy. Earlier research (Suszka, 1976) and the results of our study on seed dormancy, based on observations of seed germination and seedling emergence, are confirmed by genetic research (Stephen et al., 2003). The higher temperature at the final stage of stratification affects the control of dormancy breaking and induction of secondary dormancy in mazzard cherry seeds. Lee et al. (2006) have found, using a mass spectrometry method (MS), protein changes in relation to the breaking of Prunus campanulata Maxim seed dormancy. Prunus campanulata, similarly to Prunus avium seeds, requires warm and cold phases of stratification to break seed dormancy. Lee et al. (2006) provided evidence of the involvement of prunin and dehydrin in the response to warm and chilly conditions. On the basis of biochemical research, proteins such as dehydrin, prunin 1 precursor, prunin 2 precursor and prunin 2 were identified in this research (Lee et al., 2006).

In this study on determination of the safe range of w.c. of seeds preserved in LN, seeds from only one growing season were available. When analyzing results and formulating more general conclusions, it should be remembered that there are other environmental factors which have a serious influence on frost resistance of plants such as hardiness (Jacobs et al., 2008) or fertilization (Luis et al., 2007) for seedlings and for seeds - changing weather conditions during seed maturation (Miura and Araki, 1999; Nonogaki, 2006). The microclimate during seed maturation in different years affects the genetic information of seeds, which is modified in dissimilar years of their maturation (Nonogaki, 2006). The information can be modified at an early stage of ontogenetic development of individual seeds or mother plants (Nonogaki, 2006). All this may finally contribute to differences between seeds collected in different years in their tolerance to deep dehydration and low temperatures.

Considering the reaction of mazzard cherry seeds to the temperature of LN, it can be noticed that the seeds did not tolerate the temperature of $\mathrm{LN}$ at a relatively low level of seed water content (below 7\%, usually the safest range of seed w.c. frozen in LN). Assuming the division of species into two categories - orthodox and recalcitrant - on the basis of only one criterion, i.e. seed sensitivity to desiccation (Roberts, 1973), seeds of mazzard cherry should be classified as orthodox. However, sensitivity to ultra-low temperatures of mazzard cherry seeds after desiccation classified this species in the category of seeds which are desiccation-tolerant and LNsensitive.

\subsection{Conclusions}

In this work, threshold levels of optimal water content for seed storage in liquid nitrogen were determined in mazzard cherry seeds. Seed tolerance to deep dehydration was not associated with seed tolerance to an ultra-low temperature.

The main hypothesis of these investigations was verified: seeds of mazzard cherry desiccated to the "safe" range of water content lose viability after storage in LN, and seedling emergence obtained from such seeds was seriously lower in comparison with nonfrozen seeds.

Acknowledgements: We thank Elżbieta Drzewiecka-Pieniężna and Anna Całka for providing technical assistance during the experiments in Kórnik. Partial financial support from the State Committee for Scientific Research, Poland, grant No. 5 P06H 057 18, is also gratefully acknowledged.

\section{REFERENCES}

Bernardo-Gil G., Oneto C., Antunes P., Rodrigues M.F., and Empis J.M., 2001. Extraction of lipids from cherry seed oil using supercritical carbon dioxide. Eur. Food Res. Technol. 212: 170-174.

Bonner F.T., 1984. Glossary of seed germination terms for tree seed workers. Gen. Tech. Rep. SO-49. New Orleans, USDA forest service, Southern forest experiment station, $4 \mathrm{p}$.

Brison M., de Boucaud M.T., and Dosba F., 1995. Cryopreservation of in vitro grown shoot tips of two interspecific Prunus rootstocks. Plant Sci. 105: 235-242.

Crane J., Miller A.L., Roekel J.W., and Walters C., 2003. Triacylglycerols determine the unusual storage physiology of Cuphea seed. Planta 217: 699-708.

Crane J., Kovach D.A., Gardner C.A., and Walters C., 2006. Triacylglycerol phase and intermediate seed storage physiology: a study of Cuphea carthagenesis. Planta 223: 1081-1089.

Ellis R.H., Hong T.D., and Roberts E.H., 1990. An intermediate category of seed storage behaviour? I. Coffee. J. Exp. Bot. 41: 1167-1174. 
FAO/IPGRI., 1994. Genebank standards. Food and agriculture organization of the united nations/international plant genetic resources institute, Rome, Italy, 141 p.

Fernández M., Marcos C., Tapias R., Ruiz F., and López G., 2007. Nursery fertilisation affects the frost-tolerance and plant quality of Eucalyptus globulus Labill. cuttings. Ann. For. Sci. 64: 865-873.

Gordon A.G. and Rowe D.C.F., 1982. Seed manual for trees and shrubs. For. Comm. Bull. 59. London United Kingdom Forestry Commission. 1-132.

Graham S.A., 1988. Revision of Cuphea section Heterodon (Lythraceae). Syst. Bot. Mono. 20: 1-168.

Grenier-de March G., de Boucaud M.T., and Chmielarz P., 2005. Cryopreservation of Prunus avium L. embryogenic tissues. Cryo Lett. 26: 341-348.

Grisez T.J., 1974. Prunus L. In: Seeds of woody plants in the United States. Agriculture Handbook No 450. Washington DC: Forest Service, USDA. 658-673.

Grześkowiak H. and Suszka B., 1983. Storage of partially after-ripened and dried mazzard. (Prunus avium L.) seeds. Arbor. Kórnickie 28: 261-281.

Grześkowiak K.H., Miara B., and Suszka B., 1983. Long-term storage of seeds of Rosaceae species used as rootstock for cherry, plum, apple and pear cultivars. Arbor. Kórnickie 28: 283-320.

Helliot B. and de Boucaud M.T., 1997. Effect of various parameters on the survival of cryopreserved Prunus Ferlenain in vitro shoot tips. Cryo Lett. 18:133-142.

Hoekstra F.A., Golovina E.A., and Buitink J., 2001. Mechanisms of plant desiccation tolerance. Trends Plant Sci. 6: 431-438.

Jacobs D.F., Wilson B.C., Ross-Davis A.L., and Davis A.S., 2008. Cold hardiness and transplant response of Juglans nigra seedlings subjected to alternative storage regimes. Ann. For. Sci. 65: 606.

Jensen M. and Eriksen E.N., 2001. Development of primary dormancy in seeds of Prunus avium during maturation. Seed Sci. Technol. 29: 301-320.

Jones S.K., Gosling P.G., and Ellis R.H., 1998. Reimposition of conditional dormancy during air-dry storage of prechilled Sitka spruce seeds. Seed Sci. Res. 8: 113-122.

Kamel S. and Kakuda Y., 1992. Characterization of the seed oil and meal from apricot, cherry, nectarine, peach and plum. J. Am. Oil Chem. Soc. 69: 492-494.

Kamiński W., 1974. Spoczynek wtórny nasion jabłoni. II. Wpşyw warunków tlenowych. III. [Secondary dormancy of apple seeds II. Influence of oxygen conditions III]. Prace Inst. Sad. 18: 9-16 and $17-24$.

Katano M. and Irie R., 1991. Shoot tip culture of Japanese flowering cherry (Prunus yedoenisi Matsum.) and a possible cryopreservation of shoot tip in liquid nitrogen. Proc. Fac. Kyusyu Univ. 10: 17-27.

Kuhn A.J., Liepe K., and Schröder W.H., 1995. An improved shock freezing method fort he cryogenic storage of seeds. IUFRO XX World Congress, 6-12 August, Tampere, Finland, Poster 115.

Lee C.S., Chien C.T., Lin C.H., Chiu Y.Y., and Yang Y.S., 2006. Protein changes between dormant and dormancy-broken seeds of Prunus campanulata Maxim. Proteomics 6: 4147-4154.

Luis V.C., Taschler D., Hacker J., Jimenez M.S., Wieser G., and Neuner G., 2007. Ice nucleation and frost resistance of Pinus canariensis seedlings bearing needles in three different developmental states. Ann. For. Sci. 64: 177-182.

Miura K. and Araki H., 1999. Effect of temperature during the ripening period on the induction of secondary dormancy in rice seeds (Oryza sativa L.). Breed. Sci. 49: 7-10.

Niino T., Tashiro K., Suzuki M., Ohuchi S., Magoshi J., and Akihama T., 1997. Cryopreservation of in vitro grown shoot tips of cherry and sweet cherry by one-step vitrification. Sci. Hortic.-Amsterdam 70: $155-163$.

Nonogaki H., 2006. Seed germination - the biochemical and molecular mechanisms. Breed. Sci. 56: 93-105.

Pence V.C., 1991. Cryopreservation of seeds of Ohio native plants and related species. Seed Sci. Technol. 19: 235-251.

Roberts E.H., 1973. Predicting the storage life of seeds. Seed Sci. Technol. 1: 499-514.

Sebök J., 1968. Treatment of cherry rootstock seeds stored for several years. Kert. Szöl. Föisk. Közlem. 32: 83-88.

Shatnawi M.A., Engelmann F., Frattarelli A., and Damiano C., 1999. Cryopreservation of apices of in vitro plantlets of almond (Prunus dulcis Mill.). Cryo Lett. 20: 13-20.

Small D.M., 1986. The physical chemistry of lipids, from alkanes to phospholipids. Handbook of Lipid Res. 4. Plenum Press, New York. pp. 256-284.

Soloveva M.A., 1966. Long-term preservation of seeds of fruit crops. Reps. Soviet. Sci. 17th Int. Hort. Congr., pp. 258-266.

Stanwood P.C., 1985. Cryopreservation of seed germplasm for genetic conservation. In: Kartha K.K. (Ed.), Cryopreservation of plant cells and organs. CRC Press, Boca Raton, Florida, pp. 199-226.

Stephen J.R., Dent K.C., and Finch-Savage W.E., 2003. A cDNA encoding a cold-induced glycine-rich RNA binding protein from Prunus avium expressed in embryonic axes. Gene 320: 177-183.

Suszka B., 1962. Wpływ czynnika termicznego na ustêpowanie spoczynku nasion czereIJni dzikiej [Influence of thermal factor on dormancy breaking of mazzard cherry (Prunus avium L.) seeds]. Arbor. Kórnickie 7: 189-275.

Suszka B., 1967. Study on seed dormancy and germination of different Prunus species. Arbor. Kórnickie 12: 221-282.

Suszka B., 1970. Wieloletnie przechowywanie nasion czereśni dzikiej (Prunus avium L.) [Storage of mazzard cherry (Prunus avium L.) seeds for several years]. Arbor. Kórnickie 15: 129-138.

Suszka B., 1975. Cold storage of already after-ripened beech (Fagus silvatica L.) seeds. Arbor. Kórnickie 20: 299-315.

Suszka B., 1976. Increase of germinative capacity of mazzard cherry (Prunus avium L.) seeds through the induction of secondary dormancy. Arbor. Kórnickie 21: 257-270.

Suszka B., Muller C., and Bonnet-Masimbert M., 1996. Seeds of forest broadleaves from harvest to sowing. Paris, INRA. 1-294.

Touchell D.H. and Dixon K.W., 1993. Cryopreservation of seed of Western Australian native species. Biodivers. Conserv. 2: 594-602.

Towill L.E. and Forsline P.L., 1999. Cryopreservation of sour cherry (Prunus ceraceus L.) using a dormat vegetative bud method. Cryo Lett. 20: 215-222.

Tylkowski T, 1995. Rozmnażanie generatywne. In: Jesion wyniosły (Fraxinus excelsior L.) [Generative propagation in European Ash]. Sorus, Poznań-Kórnik. Nasze drzewa leśne [Our forest trees] 17: $157-200$.

Tylkowski T., 1998. Przezwyciężanie spoczynku nasion jesionu wyniosłego (Fraxinus excelsior L.) i lipy drobnolistnej (Tilia cordata Mill.) [Breaking of dormancy of European Ash (Fraxinus excelsior L.) and small-leaved lime (Tilia cordata Mill.) seeds. I.Z. Bartkowiak, Poznań, 1-64.

Walters C., Wheeler L., and Stanwood P., 2004. Longevity of cryogenically stored seeds. Cryobiology 48: 229-244.

Wang B.S.P, Charest P.J., and Downie B., 1993. Ex situ storage of seeds, pollen and in vitro cultures of perennial woody plant species. FAO Forestry Paper 113, FAO, Rome, Italy, 83 p. 